\title{
Источники и приемы кадрового комплектования советского атомного проекта
}

\author{
Мельникова Н.В. \\ Институт истории и археологии Уральского отделения Российской Академии наук, \\ Россия, 620990, г. Екатеринбург, ул. Ковалевской, 16 \\ E-mail: melnatvik@mail.ru
}

\begin{abstract}
Аннотация. В статье анализируются особенности формирования кадрового состава советского атомного проекта. Хронология исследования включает период между 1945 г., давшим начало активизации проекта после затяжного старта, и второй половиной 1950-х гг., когда были достигнуты основные результаты по ключевым направлениям государственной политики в области создания ядерного оружия. В динамике рассмотрены источники, механизмы и приемы «атомного» рекрутирования, структура исполнителей - научных и инженерно-технических кадров (в том числе молодых специалистов), рабочих (включая спецконтингенты), среднего технического персонала. Показано, как цель проекта, занимаемая им в советской системе позиция «главного звена», его секретность и режимность определяли интенсивность действия мобилизационных методов в решении кадрового вопроса.
\end{abstract}

Ключевые слова: советский атомный проект, кадры, кадровая политика, комплектование, мобилизация.

Для цитирования: Мельникова Н.В. 2021. Источники и приемы кадрового комплектования советского атомного проекта. Via in tempore. История. Политология, 48 (2): 457-466. DOI: $10.52575 / 2687-0967-2021-48-2-457-466$.

\section{Recruitment sources and techniques of the soviet atomic project}

\author{
Natalia V. Melnikova \\ Institute of History and Archaeology of Ural Branch of Russian Academy of Sciences, \\ 16 Kovalevskaia St., Ekaterinburg, 620990, Russia \\ E-mail: melnatvik@mail.ru
}

\begin{abstract}
The article is devoted to the specificities of the Soviet atomic project's manpower formation: how new employees were acquired and appointed in this crucial sector of the Cold War economy, and who they were. The chronology is from 1945 to the second half of the 1950s. This was the time between the beginning of the project active stage after a protracted start and its completion, when the main results in the creation of nuclear weapons were achieved. The study is based on declassified archival materials, published documents and memoirs. The author analyzes the sources, mechanisms and techniques of the «atomic» recruiting, and their changes over time. It was considered dynamics of the manpower structure: scientists (including foreign and GULAG prisoners), engineers, as well as young professionals, workers (including «special contingents» of NKVD / MVD USSR), middle technical personnel. It is shown how the goal of the project, the position of the «main element» in the Soviet system, its secrecy and regime determined the intensity of the mobilization methods in the project's personnel policy.
\end{abstract}

Keywords: Soviet atomic project, manpower, personnel policy, recruitment, mobilization.

For citation: Melnikova N.V. 2021. Recruitment sources and techniques of the soviet atomic project. Via in tempore. History and political science, 48 (2): 457-466 (in Russian). DOI: $10.52575 / 2687-0967-2021-48-2-457-466$. 


\section{Введение}

В ходе реализации советского атомного проекта были заложены основы современной национальной инновационной системы. Актуальные задачи обеспечения технологических прорывов и ускоренной модернизации российской экономики заставляют с особым вниманием отнестись к историческим достижениям в осуществлении проекта. В их числе - создание специализированного кадрового базиса. Несмотря на обширную историографию истории атомного проекта СССР [Мельникова, Бедель, 2016], проблема формирования его кадрового потенциала не получила комплексного системного освещения. Поэтому данная статья фокусируется на способах, механизмах, источниках, типах и эволюции процесса пополнения «атомных» кадров. Источниками исторической реконструкции послужили делопроизводственные документы - опубликованные и неопубликованные, отложившиеся как в центральных, так и в региональных архивах, в том числе в научный оборот вводится впервые выявленный в Центральном государственном архиве г. Москвы фонд Парторганизации Первого главного управления.

\section{Объекты и методы исследования}

Объектом исследования данной статьи является процесс кадрового комплектования советского атомного проекта в 1945 г. - второй половине 1950-х гг. В работе применены следующие методы исследования: анализ, синтез, проблемно-хронологический и историко-сравнительный методы (позволяющие проследить проблему в динамике, хронологической последовательности и выявить специфические особенности кадровой политики в советском атомном проекте). Статистические методы обеспечили представление данных, иллюстрирующих количественные характеристики отдельных групп кадрового потенциала проекта. Метод «саse studies», дополняя исследование, преодолевал ограниченность источниковой базы, связанной с секретностью проекта.

\section{Результаты и их обсуждение}

Появление ядерного оружия стало серьезным внешним вызовом СССР и расценивалось высшим руководством страны как угроза (а также как потенциальная возможность). Это ставило атомный проект на позицию «главного звена», от которого зависел успех противодействия нависшей над системой опасности [Седов, 2003, с. 21]. Такая позиция обусловила высокий уровень секретности, сопровождавший реализацию проекта. Согласно постановлению Государственного комитета обороны от 20 августа 1945 г. формировались внеправительственные и надведомственные органы управления проекта - Специальный комитет и Первое главное управление (ПГУ) ${ }^{54}$. За этим последовала тотальная мобилизация различного вида ресурсов, в том числе и людских. Нужды проекта (включая кадровые) получили право удовлетворения «преимущественно перед другими ведомствами».

Укомплектовать формируемую отрасль работниками в кратчайшие сроки можно было только путем собирания их из различных источников. Инструментом «атомного» комплектования являлась мобилизация как направленный процесс активизации масс властью для решения чрезвычайных задач, возникающих в виде различных «вызовов и угроз» [Социальная мобилизация, 2013, с. 9]. Законодательной базой перераспределения и новой концентрации кадров служил указ Президиума Верховного Совета СССР от 19 октября 1940 г. «О порядке обязательного перевода инженеров, техников, мастеров, служащих и квалифицированных рабочих с одних предприятий и учреждений в другие». Он предоставлял право народным комиссарам СССР «переводить в обязательном порядке» работников на те «участки» экономики страны, которые испытывали в них недостаток. В случае атомного проекта это происходило в ущерб действующим промышленным предприятиям. Они либо лишались уже работающих, причем лучших, либо недополучали молодых спе-

${ }^{54}$ Атомный проект СССР: документы и материалы: в 3 т. / Под общ. ред. Л.Д. Рябева. Т. II. Кн. 1. Саров, 1999. С. 11-14. 
циалистов и рабочих ${ }^{55}$. Все это было тем более проблематично, учитывая общий дефицит рабочей силы в стране, образовавшийся к концу Второй мировой войны. Недаром начальник Первого главного управления Б.Л. Ванников называл изъятие лучших кадров в пользу проекта «ограблением промышленности» [Ершов, 2019, с. 14].

Заказы на нужных работников формировали сами «атомные» объекты (как назывались научные и производственные «единицы» проекта). От невозможности «просчитать» ситуацию в условиях принципиальной новизны дела и меняющихся «техзаданий» руководители часто указывали большее количество персонала (прежде всего, рабочих и ИТР), чем требовалось в конечном итоге ${ }^{56}$. Однако руководство ПГУ, видимо, с пониманием относилось к этим сложностям: не было случаев, чтобы за явно завышенные заявки руководители наказывались выговором ${ }^{57}$.

Условно говоря, можно выделить персонифицированный заказ, который касался конкретного специалиста, известного кому-либо из уже работающих в проекте, и массовый. Последний составлялся на определенное количество работников необходимых специальностей, уровня подготовки и квалификации, в том числе на молодых специалистов и рабочих. В качестве характерного примера персонифицированного рекрутинга можно привести случай приглашения в 1952 г. в Лабораторию «В» физика-теоретика А.С. Давыдова. Его кандидатуру предложил директор упомянутой лаборатории доктор физико-математических наук Д.И. Блохинцев. Оба они были выпускниками физического факультета МГУ, учениками и представителями школы академика И.Е. Тамма. После одобрения кандидатуры Давыдова в ПГУ последовала проверка его биографии МГБ, подтвердившая, что он «достоин» работать в секретной сфере, затем было получено согласие самого кандидата. А далее случилась довольно длительная «тяжба» по переписке, поскольку ни дирекция Института физики АН УССР, где он на тот момент работал, ни президент Академии наук Украинской ССР А.В. Палладин не желали отпускать перспективного сотрудника. Блохинцев, апеллируя к главе Спецкомитета Л.П. Берии, настаивал, что не видит Давыдову никакой замены ${ }^{58}$. Дело решило распоряжение Совета Министров СССР, обязывающее Академию наук УССР откомандировать ученого в распоряжение ПГУ; в 1953 г. он приступил к работе в Лаборатории «В» ${ }^{59}$.

Данный кейс демонстрирует несколько важных закономерностей «атомного» рекрутирования. Во-первых, действие механизма «экспертного мнения», предшествовавшего последующим формализованным и неформализованным процедурам отбора и оформления в проект. Во-вторых, обязательность проверки претендента органами госбезопасности на предмет «чистоты» его биографии. В-третьих, специфичные векторы процедуры отбора. Если сведения о наличии нужного претендента могли исходить «снизу», то проведение согласования непременно должно было проходить только «сверху», через аппарат ПГУ. Так обеспечивался режим секретности, которым был пронизан проект. То, что личные инициативы таких переговоров возбранялись, показывает другой эпизод, произошедший с Б.Г. Музруковым, в 1948 г. с поста директора Уралмашзавода назначенным руководителем первого советского комбината по наработке плутония (г. Озерск ${ }^{60}$ ). По своей инициативе, без согласования с ПГУ и без предварительной проверки МГБ он повел переговоры с одним из своих бывших сотрудников о переводе его на плутониевый комбинат. Спецкомитетом это было расценено как рассекречивание информации об «атомном» объекте. Директор получил строгий выговор и предупреждение о привлечении к уголовной ответственности за нарушение правил секретности в дальнейшем ${ }^{61}$. А остальные - понятный урок, как не следует поступать.

${ }^{55}$ Государственный архив Российской федерации (далее - ГАРФ). Ф. 10208. Оп. 2. Д. 771. Л. 104, 175.

${ }^{56}$ ГАРФ. Ф. 10208. Оп. 2. Д. 1221. Л. 42; Центр документации общественных организаций Свердловской области (далее - ЦДООСО). Ф. 5673. Оп. 1. Д. 118. Л. 9.

${ }^{57}$ Центральный государственный архив г. Москвы (далее - ЦГАМ). Ф. 3466. Оп. 1. Д. 2. Л. 28.

${ }^{58}$ ГАРФ. Ф. 10208. ОП. 2. Д. 1500. Л. 1-11.

${ }^{59}$ Атомный проект СССР. Т. II. Кн. 5. Саров - М., 2005. С. 504; Т. III. Кн. 1. Саров - М., 2008. С. 477, 661.

${ }^{60}$ Поскольку закрытые атомные города имели открытые (условные) и секретные наименования, которые не единожды менялись, здесь и далее приведены современные названия.

${ }^{61}$ Атомный проект СССР. Т. II. Кн. 1. С. 266, 368-369. 
В первую очередь кадры набирались из родственных ПГУ по характеру и квалификации геологоразведочной, горнорудной, металлургической отраслей промышленности, Академии наук СССР, ведомственных НИИ, МВС, МГБ и МВД ${ }^{62}$. Поскольку нужны были не только специалисты, занятые разработкой и производством ядерного оружия и средств его доставки, но и те, кто будет обеспечивать им условия жизни, кадровыми «донорами» становились и «непрофильные» для проекта министерства - легкой и пищевой промышленности, здравоохранения, образования, культуры, торговли и т. п.

Для отбора работников согласно заказам «атомных» объектов составлялись «разверстки» специалистов по различным областям и республикам СССР (по большей части, России, Украины и Белоруссии) ${ }^{63}$. С учетом требований к квалификации (лучшие в своих сферах деятельности) и личности кандидатов («чистота» биографии, здоровье) было непросто соблюдать установку Спецкомитета «по возможности сократить количество областей, по которым предполагается производить набор кадров» ${ }^{64}$. Как отмечали работники отдела кадров ПГУ, «чтобы отобрать десятки специалистов, нужно “просеивать” многие тысячи» 65 . Поэтому полигоном отбора становилась вся страна, за исключением приграничных территорий и территорий, находившихся в годы войны в зоне оккупации. Проживавшие там априори считались неблагонадежными.

В соответствии с «разверстками» по стране распределялись представители Управления кадров ЦК ВКП(б), отдела кадров ПГУ и кадровых служб «атомных» объектов, имевшие право действовать только через первых секретарей обкомов партии. Те получали постановления, обязывавшие обком отобрать и отдать ПГУ определенное количество работников обозначенных специальностей с подведомственных им промышленных предприятий. О масштабах работы на местах может свидетельствовать тот факт, что 80 \% сотрудников отдела кадров ПГУ в конце 1940-х гг. постоянно находились в командировках по подбору персонала ${ }^{66}$.

Списки потенциальных претендентов, сформированные для одного «атомного» объекта, не были монополией только этого предприятия, а становились общим источником комплектования кадрами, которые могли быть распределены и на другие объекты ${ }^{67}$. Отбракованные кандидаты заносились в отдельную картотеку, к которой в случае необходимости обращались повторно, отбирая лучших из имеющихся в ней ${ }^{68}$. Формировались также резервные списки кандидатов на руководящие инженерно-технические должности, составляемые аппаратом ЦК. В них входили имеющие большой опыт (10-15 лет и выше) специалисты - директора крупных промышленных предприятий, главные инженеры/энергетики/механики и проч. Если руководитель какой-либо службы «атомного» объекта не справлялся со своими обязанностями, для каждой отдельной должности можно было быстро подобрать 5-8 «запасных вариантов» ${ }^{69}$.

В первой половине 1950-х гг. «атомное» кадровое комплектование посредством мобилизации через обкомы партии и предприятия постепенно сворачивалось, уступая в следующее пятилетие место другой разновидности мобилизации - общественным (комсомольским, молодежным) призывам. Они оказали заметное влияние на комплектование рабочей силой строительств закрытых городов Сибири [Реут, 2014, с. 208-210, 213, 215].

Молодые специалисты на востребованные в высокотехнологичном проекте инженерно-технические должности поступали из вузов и техникумов. В вузах для ПГУ организовывались специальные (секретные) кафедры, факультеты и отделения с отбором и переводом туда наиболее успевающих учащихся. В общей сложности было задействовано

\footnotetext{
${ }^{62}$ Атомный проект СССР. Т. II. Кн. 4. Саров - М., 2003. С. 522

${ }^{63}$ ЦГАМ. Ф. 3466. Оп. 1. Д. 72. Л. 118-119.

${ }^{64}$ Атомный проект СССР. Т. ІІ. Кн. 1. С. 320

${ }^{65}$ ЦГАМ. Ф. 3466. Оп. 1. Д. 72. Л. 58.

${ }^{66}$ Там же. Л. 112.

${ }^{67}$ Там же. Л. 26.

${ }^{68}$ Там же. Д. 132. Л. 28-30.

${ }^{69}$ ГАРФ. Ф. 10208. Оп. 2. Д. 775. Л. 17.
} 
19 вузов - в основном московские и ленинградские высшие учебные заведения (исключение составляли госуниверситеты Горького, Киева, Тбилиси, Харькова и политехнические институты Свердловска и Томска) ${ }^{70}$. Профильным вузом стал Московский механический институт (с 1953 г. - инженерно-физический) ${ }^{71}$. С 1952 г. его филиалы открывались в закрытых атомных городах. В центральных вузах «атомные» кадровики, минуя комиссии по распределению, принимали решение, кто будет направлен на «атомный» объект. Отбор проводили и «атомные» ученые, посещавшие учебные заведения. Выпускники филиалов в закрытых городах «поглощались» градообразующим «атомным» предприятием.

Своеобразным источником пополнения высококлассных специалистов были немецкие ученые, инженеры и мастера, вывезенные из Германии или обнаруженные в лагерях для военнопленных. Одни были «приглашены» и «изъявили согласие работать в Советском Союзе» (как М. фон Арденне, Р. Дёпель) ${ }^{72}$. Другие (как М. Штеенбек) считали себя принудительно отправленными в страну и оценивали это как жизнь в плену ${ }^{73}$. В публицистической литературе можно встретить утверждения, что «по атомному проекту в СССР работало 7 тысяч немецких специалистов» [Лесков, 2011]. Опираясь на доступные на сегодняшний день документы, можно сказать, что наибольшее число немецких специалистов, участвовавших в научных разработках, насчитывалось в советском атомном проекте летом 1948 г. - 324 человека ${ }^{74}$. Де-юре они не находились ни в статусе военнопленных, ни гражданских заключенных, но, хотя их положение было несравнимо лучше упомянутых категорий, труд был столь же несвободным [Колеров, 2003].

Еще одну подобную группу составляли советские специалисты-заключенные, выявленные в лагерях ГУЛАГа. Вероятно, наибольшее их количество было сосредоточено в Лаборатории «Б» (п. Сунгуль, Челябинская область) - 12 человек, среди которых находились известные ученые Н.В. Тимофеев-Ресовский и С.А. Вознесенский ${ }^{75}$. Несмотря на досрочное освобождение и снятие судимостей, произошедшее почти у всех в период работы в Лаборатории, существовавшей до 1955 г., они оставались прикрепленными к месту работы, по сути, являясь спецпоселенцами (одни - имея этот статус официально, другие даже без соответствующих документов).

Рабочие для основных производств и «атомных» строительств массово поступали благодаря системе оргнаборов. Широко используемая в стране в первое послевоенное десятилетие, она базировалась на вербовке сельских жителей [Клинова, 2019, с. 18]. В атомном проекте малоквалифицированные рабочие, завербованные напрямую из сельского населения, чаще поступали на предприятия «смежников», в то время как на объекты Первого главного управления, как правило, направлялись молодые рабочие, прошедшие обучение в школах ФЗО, ремесленных, профессионально-технических училищах ${ }^{76}$.

Для подготовки квалифицированных рабочих, младшего и среднего технического персонала в системе ПГУ появлялись «свои техникумы и прикрепленные ремесленные училища» ${ }^{77}$. За 1945-1959 гг. атомное ведомство получило путем передачи ему два училища, организовало пять; создало 11 техникумов и политехникумов, размещенных не только на территории СССР (прежде всего, в закрытых городах), но и в Германии - для обучения горняков при расположенном там советском горнодобывающем предприятии «Висмут». Таким образом, среднее профессиональное образование для атомного проекта было представлено механической, технологической, химико-технологической, химико-аналитической, электромеханической, геологической, строительной и медицинской специальностями.

\footnotetext{
${ }^{70}$ Там же. Д. 1632. Л. 48-49.

71 Там же. Л. 46-48.

72 Атомный проект СССР. Т. ІІ. Кн. 2. Саров, 2000. С. 375.

${ }^{73}$ ГАРФ. Ф. 10208. ОП. 2. Д. 830. Л. 183.

${ }^{74}$ Атомный проект СССР. Т. ІІ. Кн. 4. С. 657, 465; Кн. 5. С. 734.

${ }^{75}$ Там же. T. II. Кн. 4. С. 465-466.

${ }^{76}$ Там же. Т. II. Кн. 2. С. 67, 184; Т. II. Кн. 3. Саров - М., 2002. С. 68, 289, 421.

${ }^{77}$ ГАРФ. Ф. 10208. Оп. 2. Д. 303. Л. 94.
} 
В целом в конце 1940-х гг. на первые региональные атомные предприятия, расположенные на Урале (заводы № 817 и 813), до 40 \% работников попадали путем отбора через областные комитеты ВКП(б) (как правило, это были высококвалифицированные ИТР, служащие и рабочие); до 29,5 \% - путем передачи МВД СССР из солдат военностроительных батальонов, которые формировали кадры строек; 23,5 \% - из Министерства трудовых резервов (молодые рабочие, поступающие через оргнаборы) и 7 \% - молодые специалисты, окончившие вузы и техникумы ${ }^{78}$. В структуре работающих в Первом главном управлении в год испытания первого советского атомного заряда (1949 г.) большинство (170 тыс.) составляли рабочие основных производств; научные и инженерно-технические работники насчитывали 19 тыс. человек, служащие и младший обслуживающий персонал - 15 тыс. человек ${ }^{79}$.

В указанной численности рабочей силы не учитывались направляемые на «атомные» рудники и стройки спецконтингенты НКВД/МВД, состоявшие из заключенных (в том числе бывших), а также «указников», спецпоселенцев и находившихся в плену. Достигнув в 1948 г. более 154 тыс. человек, численность спецконтингента на стройках ПГУ в дальнейшем снижалась ${ }^{80}$. Вопрос об их замене поднимался на заседании Спецкомитета уже в 1946 г. ${ }^{81}$. Причинами были низкий уровень производственной дисциплины среди них и высокий - преступности, а также экономическая неэффективность: невысокая квалификация большинства заключенных и удорожание их содержания по мере увеличения объема работ. Однако требуемое количество строителей было столь велико, что признавалась практическая невозможность их подбора в порядке вербовки ${ }^{82}$. Проблему решали постепенно, выводя с объектов спецконтингенты, место которых занимали военные строители. К середине 1950-х гг. в Министерстве среднего машиностроения СССР (приемнике ПГУ) трудилось больше 233 тыс. военных строителей ${ }^{83}$.

В то время как в других отраслях советской промышленности в конце 1940-х - начале 1950-х гг. возрастала доля принятых по вольному найму [Соколов, 2004, с. 92], в атомном проекте эта тенденция не наблюдается. Здесь следует оговориться, что во второй половине 1940-х и начале 1950-х гг. под вольным наймом понималось трудоустройство формально свободных граждан. Поэтому к категории вольнонаемных причислялись и мобилизованные через обкомы, министерства и предприятия, демобилизованные солдаты, бывшие «указники» и спецпоселенцы, освободившиеся заключенные. Следуя такой трактовке, можно выделить довольно большую группу нанятых по вольному найму на атомное предприятие - до 15-20 \% [Жарков, 2012, с. 81]. Однако по факту о соблюдении принципа добровольности в отношении указанных социальных групп во многих случаях можно говорить лишь условно. Особенно в отношении бывших военнослужащих и спецконтингентов, которых следовало, как гласили инструкции, «оставлять на строительствах в обязательном порядке для работы по вольному найму» ${ }^{84}$. Данные категории работников в разряде «вольнонаемных» строителей в большей степени были востребованы во второй половине 1940-х гг., когда на «атомных» строительствах было оправдано применение неквалифицированного, массового труда. В течение первой половины 1950-х гг. масштабы их приема уменьшались.

Если понимать вольный найм как индивидуальное (неорганизованное) трудоустройство, основанное на личном желании, то можно сказать, что его возможности были очень ограничены. Он применялся главным образом в отношении жителей близлежащих к закрытым атомным городам населенных пунктов. На основании личного заявления наби-

\footnotetext{
78 Там же. Д. 467. Л. 31.

${ }^{79}$ Атомный проект СССР. Т. II. Кн. 4. С. 719

${ }^{80}$ Там же. С. 538, 736.

${ }^{81}$ Там же. Т. II. Кн. 1. С. 99.

${ }^{82}$ Там же. Т. II. Кн. 4. С. 509
}

83 Записка Г.К. Жукова и В.Д. Соколовского в ЦК КПСС о сокращении численности военностроительных частей // Архив Александра Н. Яковлева. URL: http:// www.alexanderyakovlev.org/fond/issuesdoc/1002862 (дата обращения: 26.03.2021).

${ }^{84}$ ГАРФ. Ф. 10208. Оп. 2. Д. 881. Л. 77. 
рали в основном рабочих и младший обслуживающий персонал. Например, за 19491950 гг. на объект № 550 (г. Саров) было принято на месте 4,7 \% ИТР от общего количества новых работников, $53 \%$ служащих и $86 \%$ рабочих и младшего обслуживающего персонала ${ }^{85}$. При этом отмечалось, что резервы соседних с объектом районов в качестве источника рабочей силы исчерпаны. Из отдаленных районов или областей по собственной инициативе устроиться на «атомный» объект было неисполнимо. Случалось, что, прознав о новом строительстве, целые семьи отправлялись наудачу из других областей к «атомным» поселениям. Однако они даже не добирались до конечного места назначения - заворачивались на ближайших железнодорожных станциях, когда проверкой документов выявлялось отсутствие направления на объект ${ }^{86}$.

С начала реализации проекта активно использовались возможности внутренних резервов - перевод работников с одного «атомного» объекта на другой. Первоначально такие внутренние перемещения затрагивали вакансии на руководящие должности - номенклатурных работников. Уже к 1949-1950 гг. потребность в руководящих кадрах системы ПГУ на $35 \%$ перекрывалась внутренними перемещениями ${ }^{87}$. С 1951 г. был взят курс на комплектование центрального аппарата ПГУ за счет «атомных» объектов ${ }^{88}$.

Позже внутренние перемещения как вид кадрового пополнения распространился и на другие категории работников. Примером массового единовременного внутреннего кадрового перемещения (не считая строителей из числа военнослужащих и заключенных) может служить создание НИИ-1011 (г. Снежинск). Его штатная численность на 1955 г. определялась в 870 человек, в том числе 600 научных и инженерно-технических работников. Больше половины от числа последних составили специалисты, переводимые из основанного в 1946 г. КБ-11 (г. Саров) ${ }^{89}$. Внутренние переводы были распространены и при строительстве «атомных» предприятий Сибири, куда направлялись квалифицированные и опытные работники с уральских объектов. С середины 1950-х гг. уже широко применялись переводы с одного «атомного» объекта на другой не только квалифицированных специалистов, но и молодежи, не имеющей опыта работы ${ }^{90}$.

В то время как до середины 1950-х гг. кадры для атомных предприятий и учреждений широко набирались по всей стране, после в Министерстве среднего машиностроения появляется установка больше использовать региональные возможности для пополнения закрытых поселений ${ }^{91}$. Это стало возможно благодаря складыванию системы «атомного» образования, в том числе на местах, и свидетельствует о переходе «атомного» Главка от чрезвычайной стадии развития к штатной (а шире - об ограничении централизованного начала советской экономики в результате ее трансформации от «командной» к «согласовывающей»). Примерно с этого же времени комплектование кадров закрытых атомных городов стало осуществимо за счет «самовоспроизводства» жителей. Хотя оно не могло полностью исключить или заменить приток рабочей силы извне, который все больше сосредотачивался на «поставках» молодых специалистов и молодых рабочих.

Зарождающееся «атомное» ведомство стремилось к стабильности кадрового состава и не любило выпускать из системы «своих». Привлеченные в атомный проект освобождались от мобилизации на любые работы «по линии партийных и общественных организаций» ${ }^{92}$.

${ }^{85}$ Подсчитано по: Докладная записка о состоянии работы с кадрами на объекте тов. Зернова П.М. // История создания ядерного оружия в СССР 1946-1953 годы (в документах) / Сост. В.В. Конюк, П.П. Максименко, А.Д. Пелипенко и др. В 8 т. Т. 2. Кн. 1. Саров (Арзамас-16), 1999. С. 31.

${ }^{86}$ ЦДООСО. Ф. 4458. Оп. 1. Д. 8. Л. 87.

${ }^{87}$ ГАРФ. Ф. 10208. Оп. 2. Д. 868.

${ }^{88}$ ЦГАМ. Ф. 3466. Оп. 1. Д. 226. Л. 32-33.

${ }^{89}$ Атомный проект СССР. Т. ІІІ. Кн. 2. Саров - М., 2009. С. 343.

${ }^{90}$ ЦДООСО. Ф. 5973. Оп. 1. Д. 149. Л. 64.

91 Там же. Д. 148. Л. 4, 7.

92 Российский государственный архив социально-политической истории (РГАСПИ). Ф. 644. Оп. 1. Д. 227. Л. 53. 
Режимность вела к тому, что на протяжении второй половины 1940-х - в начале 1950-х гг. просто уволиться было сложно, уехать только по своему желанию из закрытого «атомного» поселения - невозможно. Такие заявления рассматривались в каждом отдельном случае, и тенденция была такова, чтобы при любой открывающейся возможности оставлять работника на секретном объекте. При освобождении от одного поста работника номенклатуры «атомного» Главка необходимо было «вносить предложения о его дальнейшем использовании» на другой «атомной» должности 93 .

Однако полная герметичность проекта была недостижима по различным основаниям. Спецконтингенты, отбывшие срок, выводились из «атомных» объектов; от использования и ввоза новых постепенно отказывались. На некоторых «атомных» объектах заключенные не использовались с середины 1950-х гг. (например, на строительстве НИИ-1011 и г. Снежинска), на других спецконтингент ограниченно применялся до 1960-х гг. [Новоселов, 1999, с. 94; Реут, 2014, с. 183-184]. Демобилизованные военные строители отправлялись домой: только часть из них удавалось завербовать в качестве вольнонаемных строителей.

Во второй половине 1950-х гг., отмеченной ослаблением «атомного» режима, расширились возможности увольнения, а также выезда из закрытых поселений, которые по собственному желанию начали покидать некоторые призванные по обкомовским путевкам «возрастные» москвичи, ленинградцы, жители крупных областных городов, не прижившиеся на Урале и в Сибири. Произошел отток и научных кадров. Региональные «атомные» объекты еще в начале 1950-х гг. покинули подолгу жившие там ранее научные руководители градообразующих предприятий - И.В. Курчатов, Л.А. Арцимович, И.К. Кикоин. К концу 1950-х гг. проект оставили такие крупные ученые, как И.Е. Тамм, Н.Н. Боголюбов, М.А. Лаврентьев, Л.Д. Ландау и др. [Артемов и др., 2008, с. 51]. В определенной степени это было закономерно: к этому времени успешно был решен ряд научных проблем атомной техники, в основных чертах сформировалась атомная промышленность.

Несмотря на то, что в масштабах страны заключительный этап репатриации немецких военнопленных на родину проходил в 1950-1952 гг. [Бугай, 1996, с. 54], немецкие специалисты, участвовавшие в советском атомном проекте, дольше задержались в СССР. Основная их часть покинула страну к 1955 г. Однако некоторые еще продолжали работать, как, например, Р. Позе в Объединенном институте ядерных исследований в Дубне (до 1959 г.).

\section{Заключение}

Таким образом, по мере воплощения проекта изменялись источники его комплектования, сужалась географическая база, отьем кадров у «донорских» министерств заменялся внутренними перемещениями, подготовкой собственного персонала и наборами молодежи, проект покидали социальные группы, представленные «чистыми» учеными, иноспециалистами и военнопленными, заключенными и спецпоселенцами. Методы «атомного» комплектования, несмотря на постепенную демократизацию, заставляют определять характер «атомного» труда основной массы юридически свободных участников как «гибридного режимного» (термин С.А. Красильникова [Красильников, 2017, с. 1044]), содержащего черты свободного и принудительного труда. Мобилизационные механизмы (как применение разных степеней принуждения к труду), ослабление действия которых в конце 1940-х гг. фиксируют исследователи [Клинова, 2019, с. 51, 368], в атомном проекте были более сильны, их элементы прослеживаются до конца его реализации.

Чрезвычайный статус органов управления проектом (и их соответствующие полномочия), межведомственность, неформальные ресурсы как прием привлечения «несе-

${ }^{93}$ Выписка из Приказа министра среднего машиностроения «Об утверждении номенклатуры должностей руководящих работников, назначаемых и освобождаемых Министром» // Грани истории в документах и фотографиях. Российский федеральный ядерный центр - ВНИИ технической физики им. акад. Е.И. Забабахина [Электронный ресурс] / Науч. ред. Аврорин Е.Н., Литвинов Б.В., Рыкованов Г.Н., Волошин Н.П., Ананийчук В.Н. Снежинск, 2009. 1 CD-ROM. 
рийных» профессионалов и мобилизационные методы эффективно обеспечили скорейшее формирование «атомного» персонала требуемой квалификации. Тем самым был преодолен основной ограничивающий фактор, т. е. выиграно время, что позволило в кратчайшие возможные сроки создать отечественное ядерное и термоядерное оружие, ставшее основой военной мощи государства.

\section{Список источников}

1. Атомный проект СССР: Документы и материалы. В 3 т. Под общ. ред. Л.Д. Рябева. Москва - Саров, 1998-2010.

2. Государственный архив Российской федерации (ГАРФ).

3. Грани истории в документах и фотографиях. Российский федеральный ядерный центр ВНИИ технической физики им. акад. Е.И. Забабахина [Электронный ресурс]. Науч. ред. Аврорин Е.Н., Литвинов Б.В., Рыкованов Г.Н., Волошин Н.П., Ананийчук В.Н. Снежинск, 2009. 1 CD-ROM.

4. Записка Г.К. Жукова и В.Д. Соколовского в ЦК КПСС о сокращении численности военно-строительных частей. Архив Александра H. Яковлева. URL: http:// www.alexanderyakovlev.org/fond/issues-doc/1002862 (дата обращения: 26.03.2021).

5. История создания ядерного оружия в СССР 1946-1953 годы (в документах). Сост. В.В. Конюк, П.П. Максименко, А.Д. Пелипенко и др. В 8 т. Т. 2. Кн. 1. Саров (Арзамас-16), 1999.

6. Российский государственный архив социально-политической истории (РГАСПИ).

7. Ц Центр документации общественных организаций Свердловской области (ЦДООСО).

8. Ц Центральный государственный архив г. Москвы (ЦГАМ).

\section{Список литературы}

1. Артемов Е.Т., Волошин Н.П., Литвинов Б.В., Никитин В.И. 2008. В целях усиления работ. Уральский исторический вестник, 3: 38-58.

2. Бугай Н. 1996. Репатриация военнопленных немцев из СССР в 40-50-е годы. Обозреватель, 3: 50-54.

3. Ершов М.Е. 2019. По специальному заданию правительства (из воспоминаний). Москва, б.м., 41. Электронная библиотека «История Росатома». URL: http://elib.biblioatom.ru/text/eroshov_vospominaniya_2019 (дата обращения: 26.03.2021).

4. Жарков О.Ю. 2012. Система управления производством плутония на химическом комбинате «Маяк» в 1945-1990 гг.: дисс. ... канд. ист. наук. Челябинск, 218.

5. Клинова М.А. 2019. Государственное регулирование экономических стратегий городского населения РСФСР в первое послевоенное десятилетие. Екатеринбург, УМЦ УПИ, 428.

6. Колеров М. 2003. Военнопленные в системе принудительного труда в СССР (19451950). Отечественные записки, 3. URL: http://magazines.russ.ru/oz/2003/3/2003_3_41.html (дата обращения: 26.03.2021).

7. Красильников С. 2017. Между правом и наказанием: труд в раннесоветском обществе. Quaestio Rossica, 4: 1027-1046.

8. Лесков С. 2011. Умные парни. Москва, Время. URL: https://ebook.tips/knigi_online/r/?bid=41434a4b5267474736734f764571506666717272467843632b5059 5a5054586e506a71676f7a38666b74733d (дата обращения: 26.03.2021).

9. Мельникова Н.В., Бедель А.Э. 2016. Атомный проект СССР: современная отечественная историография и источники. Экономическая история. Ежегодник. Т. 2014-15. М., Институт российской истории РАН: 492-513.

10. Новоселов В.Н. 1999. Создание атомной промышленности на Урале. Челябинск, УралГАФК, 278.

11. Реут Г.А. 2014. Ведомственные населенные пункты Министерства среднего машиностроения СССР в Сибири (1949-1991 гг.): дис. ... докт. ист. наук. Иркутск, 600.

12. Седов В.В. 2003. Мобилизационная экономика: советская модель. Челябинск, Челяб. гос. ун-т, 177.

13. Соколов А.К. 2004. Принуждение к труду в советской промышленности и его кризис (конец 1930-х - середина 1950-х гг.). Экономическая история. Ежегодник. 2003. Москва, РОССПЭН: 74-99. 
14. Социальная мобилизация в сталинском обществе (конец 1920-х - 1930-е гг.). 2013. Отв. ред. С.А. Красильников. Новосибирск, НГУ, 418.

\section{References}

1. Artemov E.T., Voloshin N.P., Litvinov B.V., Nikitin V.I. 2008. V celjah usilenija rabot [To strengthen the work]. Ural'skij istoricheskij vestnik, 3: 38-58 (in Russian).

2. Bugaj N. 1996. Repatriacija voennoplennyh nemcev iz SSSR v 40-50-e gody [Repatriation of German prisoners of war from the USSR in the 40-50s]. Obozrevatel', 3: 50-54 (in Russian).

3. Ershov M.E. 2019. Po special'nomu zadaniju pravitel'stva (iz vospominanij) [On a special government task (from memoirs)]. Moskva, b. m., 41. Jelektronnaja biblioteka «Istorija Rosatoma». URL: http://elib.biblioatom.ru/text/eroshov_vospominaniya_2019 (accessed 26.03.2021) (in Russian).

4. Zharkov O.Ju. 2012. Sistema upravlenija proizvodstvom plutonija na himicheskom kombinate «Majak» v 1945-1990 gg. [Management of the plutonium prodaction at the Mayak chemical plant in 1945-1990]: diss. ... kand. ist. nauk. Cheljabinsk, 218 (in Russian).

5. Klinova M.A. 2019. Gosudarstvennoe regulirovanie jekonomicheskih strategij gorodskogo naselenija RSFSR v pervoe poslevoennoe desjatiletie [State regulation of economic strategies of the RSFSR urban population in the first post-war decade]. Ekaterinburg, UMC UPI, 428 (in Russian).

6. Kolerov M. 2003. Voennoplennye v sisteme prinuditel'nogo truda v SSSR (1945-1950) [Prisoners of war in the system of forced labor in the USSR (1945-1950)]. Otechestvennye zapiski, 3. URL: http://magazines.russ.ru/oz/2003/3/2003_3_41.html (accessed 26.03.2021).

7. Krasil'nikov C. 2017. Mezhdu pravom i nakazaniem: trud v rannesovetskom obshhestve [Between rights and punishment: labour in the early years of Soviet Society]. Quaestio Rossica, 4: 1027-1046 (in Russian).

8. Leskov S. 2011. Umnye parni [Smart guys]. Moscow, Vremja. URL: https://ebook.tips/knigi_online/r/?bid=41434a4b52674747736734f764571506666717272467843632b5059 5a5054586e506a71676f7a38666b74733d (accessed 26.03.2021) (in Russian).

9. Mel'nikova N.V., Bedel' A.E. 2016. Atomnyy proekt SSSR: sovremennaya otechestvennaya istoriografiya i istochniki [Nuclear project of the USSR: modern russian historiography and sources]. Ekonomicheskaya istoriya. Ezhegodnik. Vol. 2014-15. M., Institut rossiyskoy istorii RAN: 492-513 (in Russian).

10. Novoselov V.N. 1999. Sozdanie atomnoj promyshlennosti na Urale [Creation of the nuclear industry in the Urals]. Cheljabinsk, UralGAFK, 278 (in Russian).

11. Reut G.A. 2014. Vedomstvennye naselennye punkty Ministerstva srednego mashinostroenija SSSR v Sibiri (1949-1991 gg.) [Departmental settlements of the USSR Ministry of Medium Machine Building in Siberia (1949-1991)]: dis. ... dokt. ist. nauk. Irkutsk, 600 (in Russian).

12. Sedov V.V. 2003. Mobilizacionnaja jekonomika: sovetskaja model' [Mobilization economy: Soviet model]. Cheljabinsk, Cheljab. gos. un-t, 177 (in Russian).

13. Sokolov A.K. 2004. Prinuzhdenie k trudu v sovetskoj promyshlennosti i ego krizis (konec 1930-h - seredina 1950-h gg.) [Forced labor in Soviet industry and its crisis (late 1930s - mid 1950s)]. Jekonomicheskaja istorija. Ezhegodnik. 2003. Moscow, ROSSPJeN: 74-99 (in Russian).

14. Social'naja mobilizacija v stalinskom obshhestve (konec 1920-h - 1930-e gg.) [Social mobilization in Stalinist society (late 1920s - 1930s)]. 2013. Otv. red. S.A. Krasil'nikov. Novosibirsk, NGU, 418 (in Russian).

\section{ИНФОРМАЦИЯ ОБ АВТОРЕ}

Мельникова Наталья Викторовна, кандидат исторических наук, старший научный сотрудник Центра социальной истории Института истории и археологии Уральского отделения Российской академии наук, г. Екатеринбург, Россия

\section{INFORMATION ABOUT THE AUTHOR}

Natalia V. Melnikova, candidate of Historical Sciences, Senior Researcher, Center for Social History, Institute of History and Archeology, Ural Branch of the Russian Academy of Sciences, Yekaterinburg, Russia 